\title{
Огородова Е.Ю. \\ Способ совершения контрабанды алкогольной продукции и (или) табачных изделий как элемент криминалистической характеристики преступлений
}

\author{
БФУ им. И. Канта \\ (Россия, Калининград)
}

doi: $10.18411 / \mathrm{j}-05-2021-188$

Научный руководитель

Авакьян М.В.

\section{Аннотация}

На основе анализа нормативно-правовых актов и результатов изучения уголовных дел рассмотрен способ преступления как элемент криминалистической характеристики преступлений, связанных с контрабандой алкогольной продукции и табачных изделий. Сформулированы рекомендации по использованию беспилотных летательных аппаратов и иных технических средства в целях борьбы с контрабандой.

Ключевые слова: криминалистическая характеристика преступлений, способ преступления, беспилотный транспорт, контрабанда, алкогольная продукция, табачная продукция

\section{Abstract}

Based on the analysis of normative legal acts and the study of criminal cases materials, there considered features of the method of crime as an element of the forensic characteristics of crimes related to the smuggling of alcoholic beverages and tobacco products. There were also formulated recommendations for use of unmanned aerial vehicles and other technical means in order to combat smuggling.

Keywords: forensic characteristics of crimes, method of crime, unmanned vehicles, smuggling, alcoholic beverages, tobacco products

В целях эффективного расследования любого противоправного деяния необходим анализ и осмысление криминалистической характеристики данного преступления. В настоящей статье рассмотрен лишь один из основных элементов криминалистической характеристики контрабанды алкогольной продукции и табачных изделий - способ совершения преступления.

Под способом совершения контрабанды понимается совокупность действий не только по подготовке, приобретению, хранению, перемещению алкогольной продукции и (или) табачных изделий через таможенную границу, но также их сбыт, маскировка и сокрытие следов преступления.

Проведенный анализ специальной юридической литературы и материалов судебной практики показал, что все основные способы совершения преступления данной категории можно разделить на 3 большие группы: 1) перемещение через таможенную границу алкогольной продукции и (или) табачных изделий вне мест или вне времени работы таможенных органов, 2) перемещение через таможенную границу алкогольной продукции и (или) табачных изделий с недекларированием товаров или с недостоверным таможенным декларированием, 3) перемещение через таможенную границу алкогольной продукции и (или) табачных изделий с сокрытием от таможенного контроля, с использованием поддельных либо относящихся к другим товарам средств идентификации или с использованием документов, содержащих недостоверные сведения о товарах.

Все вышеприведенные способы уже устоялись, как в теории, так и на практике, обобщив, их можно охарактеризовать как «традиционные». К аналогичному выводу пришел и законодатель в Постановлении Пленума Верховного Суда РФ от 27.04.2017 № 12 "О судебной практике по делам о контрабанде" [1]. 
Рассмотрим их подробнее.

1. Перемещение помимо или с сокрытием от таможенного контроля.

Согласно пункту 41 части 1 статьи 2 Таможенного кодекса Евразийского экономического союза (далее - ТК ЕАЭС) таможенный контроль - совокупность совершаемых таможенными органами действий, направленных на проверку и (или) обеспечение соблюдения международных договоров и актов в сфере таможенного регулирования и законодательства государств-членов о таможенном регулировании [2].

Формами таможенного контроля, согласно статье 322 ТК ЕАЭС, являются: получение объяснений; проверка таможенных, иных документов и (или) сведений; таможенный осмотр; таможенный досмотр; личный таможенный досмотр; таможенный осмотр помещений и территорий; таможенная проверка.

В целях реализации данной деятельности вдоль Государственной границы Российской Федерации создаются зоны таможенного контроля.

При этом перемещение алкогольной и (или) табачной продукции помимо таможенного контроля означает пересечение таможенной границы вне установленных мест или времени, предназначенных для прохождения таможенного контроля.

По нашему мнению представляется возможным рассматривать в рамках данного способа действия, направленные на избежание процедуры таможенного контроля, даже в случаях, если пересечение государственной границы было в установленном месте или в установленной время.

Под сокрытием от таможенного контроля алкогольной и (или) табачной продукции следует понимать случаи, когда используются различного рода тайники (например, конструктивные полости транспортного средства), либо создаются скрытые полости, которые ранее были не предусмотрены, затрудняющие обнаружение контрабандного товара. Сюда относятся также случаи придания контрабандной продукции вида обычного товара, легализовано для свободного оборота.

2. Перемещение с использованием подложных документов или средств таможенной идентификации.

Под подобным перемещением понимается представление таможенному органу в качестве документов, необходимых для таможенных целей, поддельных документов, недействительных документов, документов, полученных незаконным путем, документов, содержащих недостоверные сведения, либо документов, относящихся к другим товарам и транспортным средствам.

К данному способу также относится использование поддельного средства идентификации либо подлинного средства идентификации, относящегося к другим товарам и транспортным средствам.

Исключением является недостоверное декларирование, так как это самостоятельный способ контрабанды.

При этом недостоверными документами являются подлинные документы, но содержащие недостоверные (не соответствующие истине) сведения.

В свою очередь недействительными считают документы, утратившие юридическую силу, не имеющие силы или значения вследствие неправильности, истечения срока действия и т.п.

Поддельными являются документы, которые содержат заведомо ложные сведения, либо в отдельные части документов внесены изменения, искажающие их действительное содержание.

Если же документ выдан на основе поддельных документов или заведомо ложных сведений, то он считается незаконно выданным.

Средства таможенной идентификации представляют собой наложение печатей, пломб, нанесение специальной маркировки, идентификационных знаков, проставление штампов, печатей, фотографирование и описание груза (статья 341 ТК ЕАЭС). Изменять средства таможенной идентификации или уничтожать их могут только 
таможенные органы. Исключения составляют случаи, указанные в части 5 статьи 341 ТК ЕАЭС.

Необходимый перечень документов, порядок их предоставления для проведения таможенного контроля определяется ведомственными нормативными актами Федеральной Таможенной Службы Российской Федерации.

3. Недекларирование или недостоверное декларирование.

Под ними понимается незаявление по установленной письменной, устной или иной форме достоверных сведений либо заявление недостоверных сведений о товарах и транспортных средствах, их таможенном режиме и других сведений, необходимых для таможенных целей.

Виды деклараций, а также порядок декларирования определяется статьями 104117 ТК ЕАЭС, а также ведомственными нормативными актами Федеральной Таможенной Службы Российской Федерации.

Тем не менее, усиление контроля на таможенной границе, введение компьютерных технологий, применение различных технических средств таможенного контроля привело к видоизменениям способов совершения контрабанды.

Проведенный анализ материалов судебно-следственной практики показал, что в настоящее время контрабандисты в целях перемещения алкогольной, а чаще табачной продукции в Калининградской области на регулярной основе используют последние достижения информационных технологий, в частности беспилотные летательные аппараты, а также другие технические устройства.

Развитие и выход беспилотных летательных аппаратов из узкого применения в военных, разведывательных целях, позволил получить к ним доступ широкому кругу лиц, чем, собственно, и пользуются контрабандисты.

«Беспилотник» - один из современных методов, который используется в настоящее время. Сущность данного метода заключается в том, что к беспилотным летательным аппаратам, обладающим высокой грузоподъемностью и дальностью следования, прикрепляется груз с контрабандной продукцией. Дрон по воздуху направляется на противоположную сторону границы, товар сбрасывается и аппарат возвращается в точку первоначального вылета.

Специфической особенностью данного способа является то, что беспилотные летательные аппараты, как правило, оснащены видеокамерой. Это усложняет процесс их перехвата.

В перспективе, с учетом неминуемого развития информационных технологий, a, следовательно, появления новых технических устройств, используемых, в том числе, в целях контрабанды, данную группу способов можно будет определить, как «инновационные». Между тем, на текущий момент исследований в этой области мало, и сформулировать исчерпывающий перечень инновационных способов контрабанды не представляется возможным. Несомненно, к таковым следует отнести использование беспилотных летательных аппаратов, а также беспилотных видом наземного и водного транспорта [3].

Для борьбы с подобными методами сотрудникам таможенных и пограничных органов целесообразно использовать всевозможные подавители сигналов. Однако, необходимо обратить внимание, что их радиус действия ограничен, возможность работы при низких температурах минимальна (при $-10^{\circ} \mathrm{C}$ невозможна), а заглушить сигнал возможно лишь той частоты, на которую настроен сам аппарат.

Также представляется эффективным использование тех самых беспилотных летательных аппаратов в целях борьбы с контрабандой. Необходимо оборудовать их видеокамерами и тепловизорами и периодически выпускать из разных точек вдоль границы. Тем самым возможно обнаружение теплоконтрастных целей, как живой силы, так и техники. 
Следует отметить, что помимо «инновационных» существуют и иные новые способы контрабанды. Например, так называемый способ «Айсберг», когда алкогольная и (или) табачная продукция упаковывается в герметичные пакеты или иную тару, затем крепится к водному транспортному средству, при этом находясь скрытой под водой, тем самым переправляясь водным путем, а также «Катапульта» - с её помощью продукция забрасывается через границу, где ее встречают другие участники группировки [4].

Таким образом, отличительной особенностью способов совершения контрабанды является их многообразность и вариативность. Также это является и проблемой, так как противодействие каждому способу совершения контрабанды требует разработки определенного комплекса научно-обоснованных рекомендаций по производству отдельных следственных действий и оперативно-розыскных мероприятий.

$$
* * *
$$

1. О судебной практике по делам о контрабанде: Постановление Пленума Верховного Суда РФ от 27.04.2017 № 12 (ред. от 11.06.2020) // [Электронный ресурс]. Доступ из справ.-правовой системы «Консультант Плюс».

2. Таможенный кодекс Евразийского экономического союза (ред. от 29.05.2019) (приложение № 1 к Договору о Таможенном кодексе Евразийского экономического союза) // [Электронный ресурс]. Доступ из справ.-правовой системы «Консультант Плюс».

3. Наниев А.Т. Вопросы правовой регламентации беспилотного (автономного) транспорта в Российской Федерации / А.Т. Наниев // Инновации. Наука. Образование. - 2020. - № 19. - С. 336339.

4. Бурдюг Я.О. Инновационные технологии борьбы с контрабандой алкогольной продукции и табачных изделий / Я.О. Бурдюг, Н.Б. Куроптев // Бюллетень инновационных технологий. - 2017. - T. 1. - № 1(1). - C. 15-19.

\section{Окрепилов О.Ю. ${ }^{1}$, Молчанова Е.В. \\ Правовые и экономические аспекты градостроительной деятельности в области эксплуатации жилищного фонда \\ ${ }^{1}$ Петрозаводский государственный университет (ПетрГУ) \\ ${ }^{2}$ Институт экономики КарНЦ РАН (ИЭ КарНЦ РАН)}

(Россия, Петрозаводск)

doi: $10.18411 / \mathrm{j}-05-2021-189$

\section{Аннотация}

Условия проживания населения, в том числе состояние жилищного фонда, являются важнейшими индикаторами качества жизни граждан страны и во многом определяются эффективностью социально-экономической политики в области градостроительной деятельности. Сфера жилищно-коммунального хозяйства традиционно считалась слабым звеном экономики, как в период СССР, так и в современной России. Эффективная эксплуатация жилого фонда не представляется возможной без четких правовых и экономических принципов, заложенных в градостроительном и в жилищном законодательстве, что обуславливает особую актуальность исследования особенностей содержания и эксплуатации жилого фонда в России. В данной работе удалось выявить основные проблемы в сфере эксплуатации жилищного фонда, как области градостроительной деятельности, а также определить направления, позволяющие повысить эффективность управления жилищнокоммунальным хозяйством. Предложенные рекомендации могут быть использованы для формирования и совершенствования нормативно-правовых актов в сфере градостроительства и жилищно-коммунального хозяйства, а также при разработке стратегических документов в области социально-экономического планирования. 